\title{
African Responses to the Debt Crisis: the Relevance of Public International Law
}

\author{
By John Baloro
}

\section{Introduction}

In the recent past, the plight of the indepted African states, especially those in sub-sahara Africa has received a substantial amount of discussion in various international organizations and media. This issue has for some time now been discussed by the organization of African Unity (OAU) as an aspect of the process of formulating strategies for solving Africa's enormous economic and financial problems. The centrality of the African debt question of the OAU programme was underscored by the resolution of the continental organization to hold a special session in December 1987 solely devoted to examine the debt problem and its overall repercussions on the economies of African countries. 1 In May 1988 , this question was again prominent of the agenda of the meeting of the Board of Governors of the Abidjan-based African Development Bank (ADB). It was reported that at this meeting, the then USA secretary of the Treasury, Mr. James Baker announced an apparently more receptive policy towards calls for a special treatment of the poorest indebted states of sub-Saharan Africa. He was reported to have stated that the USA would not oppose any measures unilaterally adopted by any creditor whose effect would be to ameliorate the dire economic position of indebtedness prevalent in many African states. He nevertheless added the reservation that the USA herself could not take any positive steps in this direction due to constraints of a domestic legal nature. The other major but unarticulated reason was the fear that a USA participation in such a relatively lenient programme for Africa might send the wrong signals to the Latin American countries which have larger debts. A few weeks after the USA announcement, the French government announced a programme for the reduction of interest rates and the cancellation of debts owed by the poorest African states.

\section{The Background and Nature of Africa's Debt Problems}

In as much as the African and Third World debt problems are derived from the character of the economic relationship existing between these states and the developed industrialized

1 See: Brooke Hyde, Summit on the Debt Mountain, West Africa, December 14, 1987, pp. 24292430. 
world the nature and background to the debt problem clearly antedates the "Oil crisis" of the early and mid-1970's or the foreign payments difficulties experienced by the indebted Latin American countries such as Mexico, Brazil, Venezuela and Peru. The character of the economic relationship existing between African and other Third World countries on the one hand, and the developed capitalist states on the other, has been defined by an international division of labour which has served to condemn the developing countries into the role of producers of industrial raw materials for the industries of Western Europe and North America. In most cases the raw materials are in the nature of unprocessed primary products such as cocoa, coffee, tea, sugar or minerals such as tin, zinc, or gold. In return for the export of such raw materials, the developing countries purchase manufactured goods from the industrialized countries. In an ordinary situation of balanced trade and exchange, there would be nothing wrong with the relationship existing between the two sets of countries.

However, commencing from the time of the colonial encounter to this day, the relationship has worked itself into an utterly lopsided one, consistently favouring the interests of the industrialized countries and perpetually operating to the detriment of the interests of the developing countries. A principal feature of this relationship is that the prices of the exports of the primary producers are not determined by them but are unilaterally fixed by buyers all of whom are located in the industrialized countries. Invariably, the prices of these primary products tend to be low in both absolute and relative terms and this situation is compounded by the fact that such prices tend to fluctuate from year to year and even in certain extreme cases month to month, e.g. the recent changes in the price of oil.

On the other hand, the prices of the manufactured products exported to Third World countries have continuously attained high levels. The Third World consumers of these products virtually have no influence over their pricing structure. In this state of affairs a structurally unfair and asymmetrical relationship has inevitably evolved resulting in adverse terms of trade on the side of the Third World countries. This in turn has created balance of payments difficulties for the economies of the Third World, thereby compelling them to seek resources from external sources to meet their external payments deficits. In the 1960's, a greater proportion of the external resources in the form of loans came from foreign states and international financial institutions such as the World Bank (IBRD) and the International Monetary Fund (IMF). However, as resources from the official sources became increasingly difficult to secure, Third World countries including African countries, burdened with external payments problems tumed to commercial banks operating in the international capital markets then awashed with the huge oil profits much in need of recycling.

In this connection, it must be pointed out that some commentators on the debt problem have tended to disproportionately apportion blame on the 1973 increases in the price of oil. For instance, it is common to find statements such as was made by Mr. G.F. Rea, the Deputy General Counsel of the IMF, when he addressed the 77th annual meeting of the American 
Society of International Law on: "Restructuring Foreign Debt" in 1983. On that occasion, he said:

"In recent years, the number of cases in which foreign debtors have had to seek relief has risen sharply. From an annual average of 4 reschedulings in the mid-1970's, the number rose to 7 in 1980, 13 in 1981 and 20 in 1982, although several of these involved successive reschedulings for the same country. The reasons are well known. After 1973, following the first oil shock the combined external current amount deficit of non-oil producing developing countries rose sharply, with a consequent demand for borrowing to finance these deficits. Borrowing was facilitated by the relatively easy availability of capital from commercial banks, which within a short period replaced official sources as the main suppliers of balance of payments financing to an important group of non-oil developing countries. The second oil shock of 1979 led to substantially increased deficits and an increased need for borrowing, but was followed by an abrupt change in the economic environment. Recession in the industrial countries led to a contraction in world trade and a rapid deterioration in commodity prices. At the same time, interest rates moved to historically high levels in real terms. The effect was a dramatic increase in the debt service burden of debtor countries, in a situation where their ability to service this debt was significantly reduced." 2

Other commentators who have studied the issue recently have equally noted the role of the oil price rises but have also noted both the internal and external factors affecting the development possibilities of African economies in the context of the international economy. 3 Others, such as Richard Synge, have noted the role of the continually declining value of Africa's exports to the industrialized countries. ${ }^{4}$ It must be pointed out that a view which interprets the debt problems of African and Third World countries solely or even primarily in terms of the 1973 and 1978-79 oil price rises falls far short of identifying the underlying problems. This relates to the long terms payments deficits of these countries which have been caused by the unjust terms of trade existing between these countries and the industrialized world.

Thus, the currently estimated total African debt of about US\$220 billion can only be sufficiently understood when it is explained in terms of the overall economic relations between African economies and those of the developed industrialized states. It is submitted

2 See: Graeme F. Rea, Restructuring Sovereign Debt, Proceedings of the 77th Annual Meeting, American Society of Intemational Law, 1983, pp. 312-317 at pp. 312-313.

3 See: Stephen Riley: After Baker: An Assessment of Recent International Initiatives on African Debt, a paper presented to the African Studies Association of the U.K. Conference 14-16 September 1989 , p. 1 .

4 See: Richard Synge: African Debt, Background Information and Statistics, a paper presented to the African Studies Association of the Conference, 14-16 September 1988, p. 1. 
that the debt problem is merely the superstructural symptom of this unbalanced relationship which has historically worked to the disadvantage of the less developed countries. This view is reinforced by the fact that increasingly, the debtor countries have contributed more net resources in the form of debt servicing to the creditor nations, the IMF and World Bank group than they receive annually. For instance, at the time of the special OAU session on African debts, the OAU secretariat estimated that debt servicing alone consumed about 40 percent of Africa's export eamings. At the individual country level it was estimated that Sudan's debt service ratio was 204 percent, Zambia's was 100 percent, Madagascar's was 87 percent, Togo's was 54 percent, and Malawi, Uganda and Ghana each had 50 percent.5

Thus, whilst debtor African countries have increasingly transferred substantial proportions of their net export earnings to the creditor states, international financial institutions and commercial banks, the flow of capital resources (in terms of official grants, new loans and private foreign investments) into African economies has ebbed as the years have gone by. According to studies by the United Nations, the net resource transfer to Africa has declined very sharply. In 1978, the net resource transfer came to a sum of US\$20 billion but it sharply declined to US\$ 3 billion in 1985 and by 1986, there occurred a net outflow of resources from the African continent at a time of heightened hardships being experienced by the majority of people. This state of indebtedness and the outflow of resources have caused devastating consequences on the African economies. It has resulted in shortages of essential imports, declining production and general hardships on the weakest section of the population. Many African countries have been compelled to adopt adjustment policies formulated and implemented as part of an IMF package of policy reforms. 6 In some countries such as Sudan, Tunisia, Ghana and Nigeria, the adoption of such adjustment programmes has caused politically destabilizing riots and other disturbances. Moreover, the adoption of such programmes has meant an unprecedented ceding of sovereignty over economic policy by the African governments. This has in turn meant an increase in the role and leverage of international financial institutions such as the IMF and the World Bank.

\section{The Responses of the Debtor African Countries}

What, then, have been the reactions of the African continent to this state of indebtedness and general economic malaise? African responses have been of a mixed character. A number of African countries afflicted by debt have sought to alleviate their international payments problems by renegotiating with their creditors, the terms of their loan agreements.

5 See: Brooke Hyde: op. cit. p. 2429.

6 For a recent case study of the impact of an adjustment programme on the Ghanaian economy, see Kodwo Ewusi: Equity Implications of IMF Stabilisation and Adjustment Programmes in Africa: the Case of Ghana, a paper presented to the ASUK Conference, 14-16 September 1988. 
For example, the Cote d'Ivoire, after the fall in the world market prices of her main export crops of cocoa and coffee decided in May 1987 to unillaterally suspend further servicing of its US $\$ 8.3$ billion debt. This move precipitated the subsequent commencement of rescheduling negotiations between the Cote d'Ivoire and the Paris club of creditor nations which however failed. In the case of the Federal Republic of Nigeria, the recent fall in the price of oil has brought in its wake, payments problems and the general weakening of all sectors of the national economy. The Federal Military Government has responded by adopting a structural adjustment programme which provided for a downward adjustment of the value of the national economy without a formal devaluation. It also ensured the gradual disengagement of the state apparatus from important sectors of the national economy. This programme is generally regarded as falling well short of a fully-fledged IMF package, even though it runs along IMF prescriptive lines.

As part of the programme of economic reform, Nigeria has also negotiated with both the Paris and London clubs for the rescheduling of her debts. After several difficult negotiating sessions, Nigeria concluded a rescheduling agreement with the commercial bank creditors of the London club in December 1986. This agreement involved rescheduling medium term debts totalling US\$1.5 billion and short term arrears of letters of credit amounting to US\$2 billion. 7 The terms of this agreement were not considered to be very favourable especially when compared with the terms of the Mexican rescheduling agreement. In the Nigerian agreement, the banks charged a very high interest rate and took a hard line towards the issue of providing new financing. The Nigerian government had asked the commercial banks for a sum of US\$ 600 million for the financial year 1986/87, but they only agreed to provide a sum of US\$ 320 million 8 .

In this regard, the Zambian experience is worthy of note. The fall of copper prices since 1977 has severely weakened the national economy. For many years now the country has persistently experienced difficulties in discharging its international payments. After consultations with the IMF, a programme was put in place which among other things resulted in a steep devaluation of the Kwacha, the national currency, the lifting of exchange controls, and the removal of subsidies on maize (thereby causing riots on the copper belt). However, after a brief period of implementing this programme, the President, Dr. Kenneth Kaunda, announced its repudiation and a "go it alone" policy without further IMF financial support. As far as the state debt was concerned, Zambia announced that she would unilaterally restrict her debt servicing to only 10 percent of net export eamings. The net export eamings represented the export eamings remaining after deducting payments for fuel, fertiliser, mining equipment and international air services to IATA. 9

7 See: Economic and Business News, West Africa, 7 September 1987, p. 1748.

8 See: Special Banking Supplement, West Africa, 8 December 1986, p. 2545.

9 Ibid. 
Simultaneously with these individual country responses to the African debt question moves have been made towards forging a unified continental position. These moves culminated in the holding of a special OAU summit on African indebtedness in Addis Abeba on 30 November - 1 December 1987. At this summit, the African countries stated a relatively moderate position, calling not for a unilateral repudiation of all debts. but for a 10 years moratorium on debt servicing. They further called for the conversion of more of the official loans into grants, the reduction of interest rates and multi-year reschedulings of up to 50 years with longer grace periods. The summit urged the creditor states and the international community to adopt a global approach towards the African debt question instead of the case-by-case approach advocated by the Western creditor nations. In this connection, the surnmit also called for an international conference to be hosted by the OAU and to which both official and commercial creditors will be invited to discuss the continent's debts.

It is interesting to note that inspite of all the problems involved in endeavouring to meet their international payments, no African country has in recent years repudiated any of her debt obligations. The only exception would seem to be Ghana where after the military overthrow of the civilian regime in 1972, the new government repudiated some of the country's debts dating back to the first Republic unter de late President Kwane Nkrumah. The official explanation given at the time was that some of the debts were tainted with corruption. However, when it was faced with threats to cut off suppliers credits the government soon fell into line and resumed servicing the debts. A possibly similar case relates to the Johnson Mathey Bank (JMB) in the UK. A parliamentary committee of the U.K. House of commons investigated certain dealings between this merchant bank and the Bank of England. In the course of the investigations, it was revealed that the JMB had financed dubious business deals in Nigeria. Eventhough this revelation was published and debated in the Nigerian press the Nigerian government never publicly made known its stand on the validity of these debts owed to the bank.

Generally speaking, it would seem that the most popular response of African states to their debt problems is to seek mutually agreeable ways for restructuring their loan agreements in order to provide them with sufficient breathing space within which to repay. A number of reasons account for this position. First of all, these states recognize their weak and disadvantaged position in the present economic system. They realise that unilateral action such as repudiation is likely to attract co-ordinated retaliatory measures from both creditor states and the ordinary commercial lenders. On the other hand, there is also the perception that a successfully rescheduled agreement will probably yield further financing even though this could mean an increase in the future debt. 


\section{The Responses of the International Community}

\section{i. The Paris Club of Creditors}

The Paris Club of creditors comprises the group of Western creditor states which have made official loans to African governments. These states have responded to the African debt problem by generally rejecting the notion of "debt forgiveness" which has so often been articulated by the debtor African states. The USA, especially during the Reagan administration, has been the most ardent opponent of this. The Western creditor states have also opposed any moves towards a global discussion and solution of the African debt problem. The USA has consistently stated the position that the African debtor countries must put their economies in order by subscribing to economic reform programmes prescribed by the IMF, she has also consistently stated the position that the issue of debt should be treated on a case-by-case basis and not globally. Nevertheless, certain Western govermments have converted their loans into grants and even cancelled some debts. For example, in 1987, Canada and the U.K. converted a number of loans into grants, and in 1988, West Germany and France announced the cancellation of the debts of a number of African countries. At the Toronto Economic summit of seven Western industrialized countries held in June 1988, the following proposals on the African debt problem were adopted. Creditor governments could convert some loans into grants, extend the period of maturity of loans, or reduce the interest rates below the commercial rates. The greatest obstacle to the adoption of these proposals as a generally accepted commitment by the creditor states has the vigorous opposition of the USA.

\section{ii. The Position taken by the London Club of Commercial Lenders}

Generally speaking, the response of the commercial banks to the African debt problem has not been sympathetic. In comparison to the Latin American debt, African indebtedness to these banks is relatively small and their financial exposure is accordingly small. Commercial banks do not feel as threatened by an African default as a default by the Latin American countries. They have therefore devised ways of reducing their financial commitments in Africa by methods such as discounted debt sales, conversion of debts into equity investment or the capitalisation of interest payments. In other cases, loans denominated in foreign currency have been converted into local currency debts, but the scale of this new trend has tended to be small. For instance in 1987, the World Bank estimated that the total sales for debt conversion amounted to no more than US\$ 5 billion out of a total of US\$ 30 billion owed to commercial banks. 


\section{iii. The Responses of International Financial Institutions}

Generally speaking, the IMF and the World Bank have approached the African debt problem by urging on African states a policy of economic reform enshrined in what have come to be known as "structural adjustment programmes".10 These are programmes adopted by economically beleaguered African and other developing countries under the tutelage of the IMF. Invariably, they involve policy elements such as the general contraction of state financial involvement in several aspects of national economic life, e.g. the provision of educational, health and other services or the removal of all state subsidies. The programmes ultimately call for the disengagement of the state from parastatal organizations. The close connections that exist between the IMF, World Bank and commercial banks tend to facilitate the imposition of structural adjusment programmes as conditions for the agreement of commercial banks to reschedule African debts. In practice, the attitude of commercial banks towards a particular African state now depends very much on whether or not that country has accepted to implement an IMF adjustment programme. At the same time both the IMF and the World Bank have expressed support for the allocation of more financial resources to the low income African states. The IMF has advocated the trebling of the Structural Adjustment Facility (SAF) to SDR 9 billion (US\$11.4 billion). On the other hand, the World Bank has tended to emphasize the need for the industrialized countries to replenish the resources of the IDA at a higher level. This would facilitate its soft loan operations to developing countries and African countries in particular.

\section{The Categories of Debts}

For the purposes of this discussion, it may be useful to categorise the various types of debts. This is important as it helps to explain questions dealing with the institutional framework employed to restructure official and private debts and the legal regime applicable. Official debts arise from the loan agreements concluded between sovereign states, or sovereign states and international financial institutions such as the IMF and the World Bank. As these are transactions between states or entities with an international legal personality, their legal framework will usually take the form of bilateral or multilateral treaties or exchange of notes. Such transactions may be concluded independently or as part of a broader legal framework in which will be found provisions dealing with the rights of establishment of the nationals of the contracting parties and the protection of their investments in the economies of the contracting parties.

10 For a more detailed examination of IMF devised structural adjustment programmes in Africa, see: Kodwo Ewusi, Equity Implications of IMF Stabilisation and Adjustment Programmes in Africa: the Case of Ghana; Nicholas Van Haer: Labour and Structural Adjustment in Nigeria and Ghana, all being papers presented at the Silver Jubilee Conference of the African Studies Association of the United Kingdom hosted by the African Studies Centre at Newham College, Cambridge University, 14th - 16th September, 1988. 
Another category of sovereign indebtedness arises from loan transactions concluded between sovereign states and private commercial lenders such as the big Western commercial Banks. These are contractual agreements under which the commercial banks or other private lenders agree to lend sums of money to an agency or instrument of a sovereign state. The type of state agency varies from the State Central Bank, a state owned commercial bank, a parastatal or the constituent state of a Federal state. The detailed clauses setting forth the conditions of performance, the schedules for the repayment of the principal sum, the rate of interest, default and the settlement of disputes will normally be settled in the loan agreement itself. In the 1970's, this category of sovereign loans increased dramatically as the sources of official lending gradually dwindled. It is this category of private commercial bank lenders who have grouped themselves into what has now become known as the "London Club" in contradistinction to the "Paris Club" which groups together the official lenders.

A less obvious category of state indebtedness arises from loan transactions between a foreign commercial bank and a company located in and doing business in the sovereign state. The loan will normally be contracted in foreign currency and the repayment of both principal and interest will equally be denominated in foreign currency. Such a loan transaction will be accounted as a loan transaction against state finances in so far as its liquidation will require a drawing on the foreign currency reserves of the state. For instance, the approval of the Central Bank will have to be obtained by the private borrower before foreign currency is released to facilitate the servicing of the debt. It is not infrequent that such loan transactions are guaranteed by the state and are therefore consequently assimilated into the portfolio of state indebtedness.

\section{The Legal Framework of Sovereign Indebtedness 11}

Historically, the international legal rules governing state loans, especially the loan transaction between sovereign states and private lenders, have developed as part of the law of

11 For sometime now, the area of the international legal aspects of foreign lending and sovereign borrowing has been neglected by jurists. However, the notable exceptions are the following works: F. Mann: The Legal Aspect of Money, 1971, pp. 553 et seq.; M. Schuster: The Public Intemational Law of Money, 1973, pp. 65-72; Broches: International Legal Aspects of the Operations of the World Bank, 98 Recueil des Cours 301, 1959-III; GM. White: Wealth Deprivation: Creditor and Contract Claims, in Richard B. Lillich (ed.): International Law of State Responsibility for Injuries to Aliens, 1983, pp. 149-179; Hugo J. Hahn: Public Foreign Debts and International Law, 33 Law and State, 1986, pp. 7-26; A.O. Adede: Legal Trends in International Lending and Investments in the Developing Countries, 180 Recueil des Cours, 1983, pp. 13-167; in: Loan Agreements with Foreign Sovereign Borrowers: Issues of Sovereign Immunity, Applicable Law and Settlement of Disputes, 2 Lesotho Law Joumal No. 2, 1987, pp. 101-125. 
state responsibility for the treatment of foreign nationals and their property by host states. In this regard, the more burning questions have traditionally concerned the circumstances under which a foreign state may exercise diplomatic protection in respect of her nationals who complained about infractions of their creditor rights by a debtor sovereign state. These questions have over the centuries been very controversial amongst states and publicists alike. In the early nineteenth century, the question of the exercise of diplomatic protection in respect of foreign lenders such as the holders of bonds issued by the newly independent Latin American countries, greatly soured their relations with several Wester European countries. Thus in certain instances such as occurred in Venezuela in 1912, this controversy led to resort to the use of force when a group of European states invaded Venezuela which had been indebted to certain foreign private lenders which were nationals of the invading states. This experience led the Latin American states to question the right of a state to exercise diplomatic protection in respect of its nationals as a norm of customary international law. The opposition of the Latin American states eventually crystallized into the Drago doctrine which prohibited the use or threat of the use of force by a state against another state to compel the payment of debts owed by such sovereign state to foreign nationals. 12 The adoption of the Drago doctrine by the international community was followed by the adoption of the Porter proposition by the second Hague Conference held in 1907. The proposition adopted by a vote of 39 to 5 was as follows:

"The contracting Powers agree not to have recourse to armed force for the recovery of contract debts claimed from the government of one country by the government of another country as being due to its nationals. This undertaking is, however, not applicable when the debtor state refuses or neglects to reply to an offer of arbitration, or, after accepting the offer, prevents any compromis from being agreed on, or, after arbitration, fails to submit to the award." 13

Persistent problems between host states of foreigners and their states of nationality led to further efforts by the Latin American countries towards the exclusion of the right of diplomatic protection. By the device of the calvo clause, foreign nationals who contracted with Latin American countries agreed to the insertion into such contracts of clauses which excluded the right of their home states to exercise diplomatic protection in their behalf in cases of dispute. The calvo clause became a source of great controversy between the capital importing and exporting states, with the latter category of states opposing it whilst the former group particularly the Latin American states supporting it. On the whole, it is doubt-

12 See: The Diplomatic Note of December 29, 1902, sent by Dr. Luis Drago, the Minister of Foreign Affairs of Argentina to the U.S. Department of State on the occasion of the joint intervention by Great Britain, Italy, and Germany against Venezuela. It is cited in: Briggs: The Law of Nation (2nd ed.), 1952, pp. 665 .

13 Ibid: p. 666. 
ful whether a clause such as the calvo clause could have the effect of depriving the state of nationality of the right to exercise diplomatic protection. This is because it is a supervening right vested in the sovereign state in international law and a private party is therefore incompetent to contract it away.

It should be noticed that when the Porter proposition was adopted in 1907 , there was a provision to the effect that, the pledge by states to refrain from using force to compel debtor states to discharge their debt obligations would not apply where the debtor state refused arbitration, the terms of a compromis, or failed to implement the terms of the award of the arbitration. Since 1907, modem international law has developed to such a stage that the use or the threat of the use of force as a policy tool in resolving international disputes have become illegal. The international legal order of the post World War II era, has firmly established this in Article 2 (3) and (4) of the UN charter and also Principle I of the Declaration on Principles of International Law concerning friendly relations and co-operation among states in accordance with the charter of the UN Principle I of the Declaration states as follows:

"I solemnly proclaim the following principles: The principle that states shall refrain in their international relations form the threat or use of force against the territorial integrity or political independence of any state, or any other manner inconsistent with the purposes of the United Nations.

... such a threat or use of force constitutes a violtion of international law and the charter of the United Nations and shall never be employed as a means of settling international issues."14

The foregoing provisions of the UN charter and the Declaration codify general principles of customary international law on this matter and are therefore binding on all members of the international community.

It has already been stated that the legal framework within which an inter-state loan or loan agreement between a sovereign state and an international financial institution operates is an international bilateral or multilateral treaty. The provisions of such an instrument will usually set out the amount of the loan, of payment of the principal sum and the interest and the measures to be taken on the default of either party. As an international instrument, the conclusion, validity and interpretation of the agreement will be governed by the rules of

14 See: Declaration on Principles of International Law conceming Friendly Relations and Co-operation Among States in Accordance with the Charter of the United Nations set forth in Brownlie (ed.): Basic Documents in International Law (2nd ed.), 1978, pp. 32-40. 
public international law dealing with treaties. ${ }^{15}$ Loan agreements between the IMF, the World Bank and sovereign states are equally international instruments governed by public international law and the relevant provisions and practices under the constitutive instruments of these organizations. Any disputes arising from such loans will normally be settled by arbitration on the basis of international law. The loan agreements concluded between sovereign states and private commercial banks pose rather more complicated issues. Eventhough such agreements are not to be considered as being on the same plane as public loan agreements, nevertheless in the absence of proof of any vitiating factors such as fraud, or duress, sovereign state parties are contractually committed to respect them. It is submitted that an unjustifiable breach of the fundamental provisions of such contractual agreements will not only result in a breach of contract vis-à-vis the lending commercial bank but many under certain circumstances constitute a breach of public international law. The interpretation and implementation of a typical loan agreement between a sovereign state and a commercial bank will be governed by the provisions of the agreement itself and the legal system chosen on the basis of the autonomy of the parties to govern the agreement. Eventhough in public international law, loan agreements between commercial banks and states do not have the same status as inter-state loan agreements, it is suggested that certain important principles of treaty law may by analogy be usefully applied to them also.

\section{i. The Grounds for the Invalidation of Treaties under the Vienna Convention on the Law of Treaties}

Part V, section 2 (Article 46-53) of the Vienna Convention on the Law of Treaties 16 deals with the grounds on which a treaty may be invalidated. The more relevant grounds relate to the following circumstances where it has become manifestly clear that a contracting state's consent to a treaty contravenes a rule of its internal law of fundamental importance, such a treaty will be invalidated. A contracting state may also invalidate a treaty on grounds of error where there was an error relating to a fact or situation which the state assumed to be in existence at the time of the conclusion of the treaty. However, a plea of error will not be upheld where a contracting state itself is responsible for the error or where the circumstances were such that it should have been put on notice. 17 A contracting state may also invalidate a treaty where it has been induced to conclude it through the fraudulent conduct of another negotiating state. In such circumstances, the state may invoke the fraud as invali-

15 See: Brownlie, op cit., pp. 233-266, also F.A. Mann: Studies in International Law, 1973, pp. 241255; Hugo J. Hahn: Public Foreign Debts and International Law, 33 Law and State, 1986, pp. 826.

16 See: S. 46, Vienna Convention on the Law of Treaties, set forth in Brownlie (ed.): Basic Documents in Intemational Law (2nd ed.), p. 233.

17 Ibid: Article 48. 
dating its consent to be bound by the treaty. ${ }^{18}$ Another ground of invalidation of a treaty is where the representative of a contracting state has been corrupted directly or indirectly with the aim of procuring the consent of the contracting state. 19 The existence of any of these grounds will serve to invalidate an inter-state loan agreement, a loan agreement between a state and an international financial organization and by parity of reasoning even a loan agreement between a state and a private commercial bank. The ground stated in Article 50 remains very relevant to contemporary African public life, govemment officials have often been accused of taking bribes and unauthorised commissions and other financial benefits from foreign companies and international banks doing business with African countries. It would seem that where evidence of such corruption is forthcoming, it could furnish a strong basis for challenging the validity of such a loan transaction. In practice, there are no instances where states have repudiated or unilaterally cancelled either inter-state or private debts by invoking any of these grounds. An exception to this practice was the 1977 Egyptian government's unilateral suspension of its military debts owed to the Soviet Union. Coupled with this suspension was also a ban on the export of cotton to the Soviet Union and Czechoslovakia. These measures were in relation for the arms embargo placed on Egypt by the Soviet Union during the 1973 Arab-Israeli war, thus worsening diplomatic relations between the two countries. 20

Similarly, regarding loans from the World Bank, the IMF and similar financial institutions, there have been no significant repudiations of state debts. In a study of the first twenty-five years of their operations, only a few cases were noted where the Bank refused to lend to countries because of a repudiation or default in the payment of an international debt. 21 The threat of the Bank's refusal to grant future lendings or even to influence other sources of lending has proved a sufficiently effective source of deterrence.

\section{ii. The Effect of State Succession on Debts}

In the event of the occurrence of state succession, the question which often arises is what happens to the debts incurred by the predecessor state. The phenomenon of state succession may occur in a number of forms e.g., where an existing state is divided into two or more states through for example secession, or the creation of a newly independent state from a formerly dependent territory. There may also be state succession where two states have united to create a single state. For the present purposes, in view of the recent emergence of most African states from colonial rule, the enquiry will focus on the rights and duties of

18 Ibid: Article 49.

19 Ibid: Article 50.

20 See: Gilian M. Whiteman: op. cit., p. 157.

21 See: E. Mason \& R. Asher: The World Bank since Bretton Woods, 1973, pp. 155-157. 
newly independent states vis-à-vis the debts incurred by the colonial predecessor state. Opinion on this question has tended to be divergent. Western jurists state the view that there is an international legal rule of automatic succession by the newly independent state to the debts and other financial obligations incurred by the predecessor state. 22 On the other hand, the Eastern European states supported by the newly independent states of Africa and Asia have denied the existence of such an international legal rule. They have argued that in a situation of decolonisation and revolutionary change, a completely new order is established and therefore the new state is not bound by financial commitments concluded to serve the interests of the colonial power. It is further argued that in many cases, these financial commitments operate to strangle the economic development of the young nations. In any case, it is pointed out that the past practice of leading Western European countries such as the United Kingdom, the USA and financial institutions such as the World Bank does not support the principle of automatic succession. The position of the socialist states and the Third World has been expressed by Yilma Makonnen as follows:

"Finally the conclusion that could be drawn from the past practice of states and the opinions of jurists that there is no clear rule of state succession in public international law determining the status of public debts. Whatever evidence is available clearly supports the clean-state doctrine or the optional doctrine of state succession." 23

It is this position which is reflected in the Vienna Convention on succession of states in respect of state property, archives and debts which was adopted by the UN General Assembly in 1983.24 Part IV of the Convention deals with the impact of state succession on state debts. Article 33 has defined a state debt as follows:

"For the purposes of the articles in the present part 'state debt' means any financial obligation of a predecessor state arising in conformity with international law towards another state, an international organization or any other subject of international law."

A pertinent observation to be made on this definition is that the convention excludes debts owed by the predecessor state to private individuals and companies. The more relevant

22 See: D.P. O'Connell: International Law, vol. 1 (2nd. ed.), 1970, pp. 383-386.

23 See: Yilma Makonnen: International Law and the New States of Africa, A Study of the International Legal Problems of State Succession in the Newly Independent States of Eastem Africa, 1983, pp. 371-410, at 373.

24 See: UN General Assembly, UN Conference on Succession of States in Respect of State Property, Archives, and Debts, Vienna, 1 March - 8 April 1983, set forth in 22 I.L.M. pp. 298-329 (Number 2, March 1983). The Convention was adopted by a vote of 54 in favour to 11 against with 11 abstentions. The opposing states included Belgium, Canada, France, F.R.G., the U.K. and the USA. 
provisions dealing with the effect of state succession on the state debts of newly independent states are provided in Article 38. It states as follows:

1. "When the successor state is a newly independent state, no state debt of the predecessor state shall pass to the newly independent state, unless an agreement between them provides otherwise in view of the link between the state debt of the predecessor state connected with its activity in the territory to which the succession of states relates and the property, rights and interests which pass to the newly independent state.

2. The agreement referred to in Paragraph 1 shall not infringe the principle of the permanent sovereignty of every people over its wealth and natural resources, nor shall its implementation endanger the fundamental economic equilibria of the newly independent state."

On the basis fo this legal position, after the independence elections in November and the attainment of independence, the new state of Namibia will not be bound wholesale by the debts and other financial commitments assumed by the Republic of South Africa. In any case since 1966, the UN General Assembly 25 and the Security Council26 terminated the South African mandate over the territory of Namibia. The legal validity of this decision was subsequently confirmed in an Advisory Opinion given by the ICJ27 thereby rendering illegal the continued presence of South Africa in the territory. This meant that the international community was under a legal obligation to desist from recognizing the continued presence of South Africa in Namibia or entering into any dealings with that state with respect to Namibia. Furthermore, it meant that apart from the exceptions stated in the Advisory Opinion all other acts, dealings and transactions purportedly concluded by South Africa on behalf of Namibia were tainted with illegality. Obviously the government of an independent Namibia will be under an international legal duty to renounce all such commitments which South Africa purported to conclude on behalf of Namibia.28 For this reason, the $1977 / 78 \mathrm{UN}$ Conference on succession of states in respect of treaties declared that "South Africa is not the predecessor state of the future state of Namibia". In 1983, the UN Conference on succession of states in respect of state property, archives, and debts, "resolved that the relevant articles of the Vienna Convention on succession of states in

25 See: General Assembly Resolution 2145 (XXI), October 27, 1966 GAOR, 21st session, supplement 16, p. 2. The Resolution was adopted by 114 votes to two (Portugal and South Africa), with three abstentions (France, Malawi and the U.K.).

26 See: UN Security Council Resolution 264 (1969) and 269 (1969) and 276 (1970).

27 See: Legal Consequences for States of the Continued Presence of South Africa in Namibia (South West Africa) Notwithstanding Security Council 276 (1970) Advisory opinion, I.C.J. 1971, p. 16

28 See: Yilma Makonnen: Namibia: Its Intemational Status and the Issues of Succession of States, 3 Lesotho Law Joumal, No. 1, 1987, pp. 183-217. 
respect of state property, archives and debts shall be interpreted in the case of Namibia in conformity with United Nations resolutions on the questions of Namibia and that in consequence, all the rights of the future independent states of Namibia shall be reserved".

\section{iii. The Principle of Changed Circumstances and the Question of National Debts}

It is useful to consider the effect of a change of circumstances on the continued validity of loan agreements concluded by sovereign states. This issue is of current interest to African and Third World countries because of the recent dramatic deterioration of their economies. Among many other complex factors which account for this have been the unexpectedly steep rises in the prices of petroleum. Can these countries plead financial inability to pay in justification of a repudiation of their debts or the unilateral declaration of a moratorium on the servicing of such debts? With respect to the law of treaties, Article 62 of the Vienna Convention on the law of treaties deals with the circumstances under which a treaty may be terminated due to a fundamental change of circumstances. This ground cannot be successfully invoked unless certain strictly defined requirements have been met. These are that:

"1. ...

a) the existence of those circumstances constituted an essential basis of the consent of the parties to be bound by the treaty; and

b) the effect of the change is radically to transform the extent of obligations still to be performed under the treaty."

In terms of the current phrasealogy of this article, for a debtor state to successfully plead the principle of fundamental change of circumstances, it would have to prove that the parties contemplated that were such a change to occur, it sould affect their ability to carry out the terms of the transaction. It would therefore seem that in order to enable it to rely on such a ground, the debtor state must during the period of negotiations ensure that the loan agreement contains a clause allowing it to suspend payments on both principal and interest in the event of severe economic difficulties. In practice, it would be difficult for a debtor state in dire need of credit to be able to wrestle such a concession from a lending state or bank.

It should nevertheless be pointed out that taking into account the dire financial state of the national economy in the management of sovereign debt is not entirely without precedent. The London Debts Agreement of February 27, 1953, concluded between the victorious Allied Powers and the Federal Republic of Germany, perhaps represents the most comprehensive attempt yet made to regulate the debts of a single country. The principle which underlies all the treaties forming the basis of the agreements is that of the ability of the 
debtor state to pay. The same principle underlined the agreements between the victorious powers, on the one hand, Italy and Japan on the other. 29 In 1961 and 1969, there were revaluations ot the German mark which brought into dispute the interpretation of a monetary stabilization clause inserted into the London Debts Agreement on Germany. The dispute was presented for resolution by the Arbitral Tribunal for the Agreement on German External Debts. 30 The principal issue before the tribunal was whether the currency of repayment of the German loans was the revalued mark with the smallest devaluation within the $5 \%$ clause in the London Debts Agreement. An affirmative response would mean that the debts would be serviced according to the higher value of the mark. The tribunal decided the issue in favour of the Federal Republic of Germany. As part of its reasoning justifying the decision arrived at, the tribunal explained the rationale of the London Debts Agreement as follows:

"A prerequisite of the fullest possible settlement with its creditors was the recovery of the German economy. This recovery, therefore, became as much the object of the treaty as the settlement of the debt itself. Eventhough the Federal Republic of Germany was fully prepared to guarantee the external debt for the pre-war period as well, the LDA's object could be achieved only if foreign creditors were prepared to waive a substantial part of their claims and to come to terms with the German debtors on conditions for payments of what remained. The object of the LDA is therefore such that, when interpreting the individual provisions of the LDA, one has always to take into consideration the particular concern of the contracting parties, while formulation the LDA, with maintaining in all parts the delicate balance between, on the one hand, the justified aim for adequate satisfaction of the creditors and, on the other, a desire not to burden the debtors with an economically intolerable load and so jeopardise successful implementation of the settlement." 31

So far, no Third World or African country has invoked the sudden quintupling of oil prices and the fall in the export revenues of developing countries as instances of force majeure. This is due to the stringent burden of proof required by international tribunals. For instance, in the Russian Indemnity Award32, the Permanent Court of Arbitration held that Turkey would have to prove that the payment of the sum due to the Russian govemment "would imperil the existence of the Ottoman empire or seriously compromise its internal or external situation". Turkey had adduced evidence to the effect that for the previous twenty

29 See: H. Hahn: op. cit., p. 21.

30 See: Arbitral Tribunal For German External Debts: Judgement in the Case of Belgium, France, Switzerland, the U.K. and the U.S.A. v. The Federal Republic of Germany, May 16, 1980, 19 I.L.M. No. 6, November 1980, pp. 1357-1408.

31 Ibid: at p. 1377, paragraph 30 of the Award (Emphasis supplied).

32 See: Russian Indeminity Arbitration (Russia v. Turkey), 11 R. Intemational Arbitration Awards, 1912, 431, also in 7 AJ.I.L., 1913, 178. 
years, it had suffered financial difficulties of the utmost seriousness caused by both domestic and external events. Consequently, it was forced to make special application of a large part of its finances, to undergo foreign control as to the management of its finances, and to grant even a moratorium to the Ottoman bank. In effect, it was placed in a financial position in which it sould meet its engagements only with delay and postponements. There was however evidence showing that Turkey had managed to raise loans at favourable rates during the same period, redeem other loans and pay off a large portion of its public debt. On the strength of these facts, the court rejected the plea of force majeure.33 Similarly in the Michel Mair Case ${ }^{34}$, the Turkish Mixed Arbitral Tribunal applied this strict test for discharging the burden of proof of force majeure. The Tribunal stated the position as follows:

"It is axiomatic that force majeure, in order to release a person from his obligation, must be of such a nature as to make it impossible for him to fulfil the obligation to which he is subject. It does not suffice that the alleged casus fortuitous, without preventing the fulfilment of the obligation, merely makes it more onerous."

Thus it is understandable that reliance on force majeure by developing countries with respect to the discharge of their debt obligations, have been very rare.

\section{iv. Debt Forgiveness and International Law}

In various international institutions for a many developing countries including those in Africa have called on the creditor developed countries to cancel debts or convert them into grants or soft loans. Earlier in the discussion, it was noted that countries such as France, Canada, the U.K. and the Nordic Countries have announced schemes for debt cancellation and convertion. However, these countries together with other developed countries especially the USA and the Federal Republic of Germany have vigorously opposed any suggestions that there is an international legal duty to forgive the debts of developing countries. Since the 1960's the call for the debt relief has formed a broad programme launched by developing countries for the transfer of substantial resources from the developed to the developing countries. This has been articulated in all the UNCTAD Conferences commencing from 1964, the UN General Assembly and the specialised organs of the UN. These efforts culminated in the adoption by the General Assembly of the 1974 resolu-

33 See: G.M. White: op. cit., p. 159.

34 See: 7 Trib. Arb. mixtes, 1982-3 (1928), also translation in B. Cheng: General Principle of Law As Applied By Intemational Courts and Tribunals, 1953, 227. 
tions calling for the establishment of a New International Economic Order ${ }^{35}$, and the Charter of Economic Rights and Duties 36 provided as follows:

"1. All states should respond to the generally recognized or mutually agreed development needs and objectives of developing countries by promoting increased net flows of real resources to the developing countries from all sources, taking into account any obligations and commitments undertaken by the state concerned, in order to reinforce the efforts of developing countries to accelerate their economic and social development.

2. In this context, consistent with the aims and objectives mentioned above and taking into account any obligations and commitments undertaken in this regard, it should be their endeavour to increase the net amount of financial flows from official sources to developing countries and to improve the terms and conditions thereof." 37

In both UNCTAD and the UN General Assembly, the developed countries have vigorously opposed the thrust of these resolutions and specifically the aspects calling for debt cancellation or relief. They have taken the view that UN General Assembly resolutions are merely of a recommendatory effect and do not therefore express binding norms of international law.38 A full evaluation of all the arguments of the legal effect of UN General Assembly resolutions is considered well beyond the scope of this paper. Nevertheless, it may be commented that where such resolutions have been adopted after a long span of debate and negotiations among the various groups of states represented in the international community, they have the effect of furnishing evidence of probative value showing the attitude of the overwhelming majority of states on the particular matter at issue. This said, it is submitted that at the present stage of the development of the branch of international law dealing with international economic relations, in the absence of specific treaty provisions there has not as yet emerged a norm mandating the donation of economic aid in whatever form and specifically in the form of debt relief.

35 On 1 May, 1974, the sixth Special General Assembly of the UN adopted Resolutions entitled: Declaration on the Establishment of a New International Economic Order and Programme of Action on the Establishment of a New International Economic Order, G.A. Resolutions 3201 and 3202 (VI) respectively.

36 See: G.A. Resolution 3281 (XXIX).

37 Ibid: Article 22.

38 See: A. Akisanya \& A. Davis: The New Intemational Economic Order, 33 I.C.L.Q., January 1984, pp. 208-217 esp. pp. 214-215; Maurice Flory: Adapting intemational Law to the development of the third world, 26 J.A.L. No. 1, 1982, pp. 12-20 esp. p. 19. 


\section{v. Aspects of Human Rights and the Debt Question: the Right to Development}

It is proposed to briefly raise the question of the inter-link between the developing countries (including African countries) demand for debt cancellation and the alleged right of peoples and states to development. Bound up with this question is the practice of the imposition of certain conditions by creditor states and financial institutions on debtor countries. The Implementation of such conditions effectively results in the erosion of the enjoyment by the population of basic human rights such as food, health and shelter. The contemporary African socio-economic scene is riddled with various structural adjustment programmes imposed by the IMF and the World Bank. As discussed earlier, on the whole, the implementation of these programmes has wreaked untold hardships on the vulnerable sectors of the citizenry of these states which have adopted such programmes. In many cases such as Nigeria, Sudan and Egypt the adoption of these programmes has resulted in the politically motived riots thereby causing political instability. There is therefore a link between human rights standards and aspects of creditor behaviour which may fall foul of them. In specific cases, problems such as whether or not the state has actually consented to the lender's programme rather than being coerced into it and the causal link between the programme and the economic conditions prevailing in the country will arise. Inspite of such problems, it pays for human rights lawyers to take account of the following observations made by Gilian White:

"International lawyers have been perhaps too ready to examine human rights issues within particular countries as if those countries were isolated units and as if those governments were able to pursue policies and propose laws without regard to outside pressures. It is important that international scholars working on human rights issues examine the nature and degree of pressure placed upon debtor governments by major creditors." 39

An important aspect of the growing link between human rights issues and the economic problems of developing countries is the question of the right of development as a human right vesting in peoples, as represented by the state and having the individual as its central subject. The right to development of people has been articulated and developed in various international organizations such as the UN General Assembly40, the Commission on Human Rights 41 , the Conference of Heads of State of Non-Aligned Countries 42 and the

39 See: $G . M$. White: op. cit. p. 171.

40 See: UNGA Res. 34/46 (1979).

41 See: CHR Res. 4/33 (1977), Res. 10/34 (1978), Res.45/35 (1979), Res. 67/36 (1980), Res. 36/37 (1981).

42 See: UN Doc. A/34/542 (1979) Annex, para. 1, 266. 
Assembly of Heads of State and Govemment of the OAU ${ }^{43}$. Academic writers and jurists have also examined various aspects of the right to development as a human right. 44 These efforts have culminated in the adoption by the UN General Assembly in 1986 of a Declaration on the Right to Development. 45 Article I (1) of the declaration stresses that the right to development by virtue of which every human person and all peoples are entitled to participate in, contribute to, and enjoy economic, social, cultural and political development. Furthermore, Article I (2) provides that the right to development implies the full realization by peoples of the right to self-determination which includes the exercise of their inalienable right to full sovereignty over their natural wealth and resources. Article 3 places a duty on all states to create the national and international environment conductive to the exercise of the right to development. States also have a duty to co-operate to ensure development and the removal of all obstacles to the attainment of this goal. In the General Assembly, the declaration failed to be adopted by consensus and was opposed by the USA, four Nordic countries, Japan, the U.K. and the Federal Republic of Germany. From the explanations of their votes two grounds for the opposition emerged. They took the view that priority should be given to individual as opposed to peoples or state human rights. Secondly they argued that the giving of assistance to developing countries by the developed ones was not mandated by norms of international law. The declaration may be critised on many other grounds such as the numerous generalizations it contains and its programmatic nature. Nevertheless, considering that an overwhelming majority of states supported it one may agree with Roland Rich when he stated:

"The objections expressed to the Declaration, some of which were also shared by countries voting in favour of Resolution 41/128, must be given due weight when assessing the degree of acceptance of the Declaration in the international community. The adoption of the Declaration by such a broad majority should be seen as an important and perhaps decisive step in the progress of the right to development to the status of international law. While the dissenting opinions are significant, there is a likelihood that dissent will wane as the years pass and as the Declaration is given practical application." 46

Perhaps, a sign that the declaration is being given practical application is to be found in Article 22 of the African Charter on Human and People's Rights which provides that:

43 See: Banjul Charter on Hurnan and Peoples' Rights, OAU Doc. CAB/LEG/67/3/Rev. 1-5, also 21 I.L.M. No. 1, January 1982, pp. 58-68.

44 Mohammed Bedjaoui: The Right to Development and the jus cogens, 2 Lesotho Law Journal, No. 2, 1986, pp. 93-129; M. Bulajic: Principles of International Development Law, 1986, pp. 332-345; Roland Rich: The Right to Development: a Right of Peoples?, in James Crawford (ed.): The Rights of Peoples, 1988, pp. 39-54.

45 See: Declaration on the Right to Development, 4 December 1986, U.N.G.A. Resolution 41/128.

46 Roland Rich: op. cit., p. 53. 
"1. All peoples shall have the right to their economic, social and cultural development with due regard to their freedom and identity and in the equal enjoyment of the common heritage of mankind.

2. States shall have the duty, individually or collectively, to ensure the exercise of the right to development."47

The foregoing provisions may carry other import by they should not impel one to a conclusion that they mandate an internationally enforceable duty to render economic assistance. One must not lose sight of the fact that they are part of the provisions of a regional human rights instrument to which the potential addresses of such a normative duty are not contracting parties. On the whole, of international law. It can be said to be a putative norm which is emerging more in the fashion of lex ferenda rather than lex lata. The position has been correctly expressed by a leading commentator in this area as follows:

"The right to development ... appears not to have attained the definitive status of a rule of law despite its powerful advocates. Its inclusion in the African Charter will be as effective as the Charter itself. The negative duty not to impede the development of states may go down well; the positive duty to aid such development, in the absence of specific accords, is a higher level of commitment that still rests on non legal considerations." 48

Consequently, it is doubtful whether the invocation of the right to development as an "inalienable human right" is capable of sustaining the argument that there is an international legal obligation on the part of creditors to cancel debts or otherwise offer debt relief to African countries. This of course does not bar the two groups of states from concluding either multilateral or bilateral agreements to this effect.

\section{The Options available to African Debtor Countries}

It has clearly emerged from the foregoing discussion that the calls by African debtor states for their creditors to draw up a programme of substantial debt-relief have been largely unsuccessful. Even assuming that all of Africa's creditors cancelled all her debts, it would only offer a temporary palliative. It is submitted that the fundamentally structural problems will remain and sooner rather than later, African countries would have to grapple with the

47 See: Article 22, African Charter on Human and Peoples' Rights, Doc. CAB/LEG/67/3/Rev. 5 (1981), also set forth in 21 I.L.M. No. 1, January 1982, pp. 58-68.

48 See: U.O. Umozurike: The African Charter on Human and Peoples' Rights, 77 AЛL, 1983, 902, at 907. 
debt problem again. African states in alliance with other less developed countries must strive to restructure the texture of their economic relations with the industrialized countries. This calls for a rejection of the current international division of labour in which they are only suppliers of industrial raw materials and purchasers of manufactured products from the industrialized world. It is this structurally imbalanced relationship which has historically caused and will continue to cause international payments problems for African and other less developed countries. In this connection, these states must redouble their efforts to roll back the trade restrictions placed by the industrialized countries against their exports of manufactured, processed and semi-processed goods. Also, the movement towards the creation of more inter-African trading links such as the establishment of various regional groupings like ECOWAS, and the PTA must be accelerated.

It is thought that African countries within the foreseeable future will continue to seek funds for economic development in the international capital markets. It is, therefore, essential for them to buttress their bargaining strength through closer consultation and co-ordination among themselves in their dealings with creditors. In financial negotiations, relevant information on the availability of funds elsewhere, the various rates of interest charged by competing lenders is crucial. Better co-ordination and consultation will facilitiate easy recycling of such useful information which may be available to one African country but not to the other. It is worrying to note that in the negotiations for the rescheduling of debts under the auspices of the Paris and London clubs, the creditors especially the Commercial Bank Co-ordinate their strategy and are normally represented by one agent. In the case of the debtor state, this is often lacking.

There is some precedent for taking into account the principles of economic changes and the financial inability of the state to pay in the management of international debts. It is therefore suggested that in future loan agreements, African govemments must insist on expressly including a link between the rate of debt servicing and the performance of the national economy. Such a clause will provide some flexibility to debtor states when their economies deteriorate to such an extent as to hamper the smooth servicing of their debts. Such a clause need not operate only to the benefit of debtors, as the rate of repayment of debts could be accelerated when the debtor state's economy improves.

\section{Summary and Conclusion}

This paper has attempted to consider the buming issue of indebtedness which is of such great interest to African and other developing countries. The consideration of this apparently purely economic problem has been from the perspective of public international law. Inter-state loans will normally operate within the framework of either multilateral or bilateral treaties. The law governing the loan will generally but not exclusively be govemed 
by principles of public international law such as the law of treaties and state responsibility. By analogy, aspects of the law of treaty will govern loan agreements concluded between states and private commercial banks. In respect of official debts, a unilateral repudiation or cancellation of a debt by a state will directly engage that state in international responsibility on the ground of a breach of a treaty. In the case of non-official loan transactions a unilateral repudiation in the absence of the infringement of reaty provisions, arbitrariness and discrimation will not engage the state in international responsibility. In practice with respect to both of ficial and private loans, unilateral repudiation has been rare indeed due to the inter-play of largely non-legal factors. For instance, a unilateral repudiation of a debt by an African state is most likely to attract both trade and financial retaliation from the creditors. African countries have failed to invoke the principles of changed circumstances and force majeure in justification of a policy of unilateral suspension of the servicing of their debts. The reason for this being the stringent natur of the burden of proof on the party alleging a change of circumstances or force majeure. Reliance has however been placed on calls on the creditors to cancel debts or otherwise offer debtor countries debt-relief. There is now an evolving trend to place this call on creditors on a legal basis derived from the UN resolutions dealing with the new international economic order and the declaration on the right to development. It is however doubtful whether these instruments which carry a certain amount of weight, impose an international legal duty on developed countries to transfer resources to developing countries. It is perhaps the sober realisation of the weakness of positive international law in this sphere which has led African debtor states to embark on negotiations with their creditors for debt rescheduling on the basis of the consent of all the parties. 


\title{
ABSTRACTS
}

Responsibility of the International Commercial Banks for Damages caused by the External Debt Crisis in the Third World

\section{By Salvador Dario Bergel}

In the 1970's the massive external debt of the Third World resulted in a phenomenon which cannot simply be analyzed under quantitative aspects, because it caused a wide variety of consequences. The article deals with the legal responsibility of intemational commercial banks, as they play a leading role in this context.

Within the internal law of the countries involved which are characterized by different legal systems in-depth research has recently been made on questions regarding the responsibility of the respective bank for its extensive loan policies. On the basis of a comparative approach the responsibility of the international commercial banks is reviewed with regard to, inter alia, the responsibility of the members of a banking consortium and the applicable law.

The article concludes that the granting of extensive loans to debtors in the Third World violated the fundamental principles and rules of banking. The damages resulting out of this violation demand for reparation.

\section{African Responses tho the Debt Crisis: The Relevance of Public International Law}

\author{
By John Baloro
}

The author examines the international legal aspects of African indebtedness. He discusses the various international responses, both African and otherwise which have evolved in relation to the debt position. Furthermore, the author considers what norms of general international law may be invoked in a bid to resolve this important contemporary problem facing Africa and the intemational community. 